\title{
The Right to Vote in South-Africa - A hundred Years of Experience
}

\author{
By Klavs Skovsholm
}

\section{Introduction}

In April of 1994, the World looked somewhat in disbelief at the almost unthinkable: South Africa's first ever multiracial elections took place peacefully under the Interim Constitution put in place then. In the year 1999, South Africa will once more be attracting the World's attention with the resignation of President Nelson Mandela and the second multiracial elections under her now Final Constitution; ' stitution $^{2}$ in force for the 1994 elections, has been drawn up by a directly elected Parliament and a constitution which does not guarantee small parties representation in the government.

The purpose of this article is to provide a non-South African reader with a better understanding of the legal and historical developments leading up to the fundamental changes in South Africa's political system by means of the first multiracial elections and of which the 1999 elections are the completion. The presentation proposed here of the Interim Constitution and the Final Constitution, which has since come into force, is not a traditional, systematic presentation of their provisions, but instead it focuses on two of the constitutional principles new to South Africa, namely the universal right to vote (franchise) and the supremacy of the Constitution. These two principles may be considered to be the most important ones in South Africa's new constitutional arrangement.

To this end it is useful to take a closer look at the franchise in a historical context. The reason for this is two-fold. First, the issue of franchise has always been at the core of the power struggle in the country: for the first time in South African history the Interim Constitution introduced a universal right to vote; a right evidently maintained in the Final Constitution. ${ }^{3}$ Second, the history of the franchise illustrates the underlying reasons for introducing the principle of supremacy of the Constitution. ${ }^{4}$ Through looking at the history

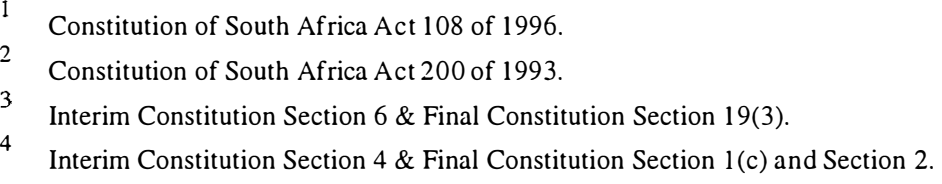


principle of the supremacy of the Constitution) we can take a closer look at other related issues such as the chapter on fundamental rights including equality before the law, ${ }_{5}^{5}$ the testing rights of the courts, and the rules regarding bills amending the Interim Constitution. ${ }^{6}$ Finally, we shall look at the way the Interim Constitution has been construed in order to serve as a guideline for the Final Constitution and the provisions in the Final Constitution which are the result of these guidelines.

\section{Pre-1909 Constitutions}

The issue of franchise finds its roots in the period leading up to the end of the last century. However, in a strict sense South Africa's constitutional history only began on $20^{\text {th }}$ September 1909 when the British Parliament adopted an act to constitute the Union of South Africa (hereinafter referred to as the South Africa Act of 1909).

The Union was the result of two bitter wars between the two white population groups, namely the English-speaking South Africans and the Dutch/Afrikaans-speaking South Africans or Boers as they were called at the time (hereinafter referred to as Afrikaners). The wars are normally referred to as the Boer Wars. ${ }^{8}$ The last of these wars took place between the two independent Afrikaner republics, The Transvaal and The Orange Free State, in the North and the British colonies in the Cape and the Natal.

When the last war ended in 1902 the British were eager to reconcile the two white population groups, and in the peace treaty Article 8 stipulated that there was to be no franchise for the natives until after ${ }^{9}$ the introduction of self-government. The obvious, but not officially stated implication was that this was never going to take place. ${ }^{10}$

Interim Constitution Chapter 3 \& Final Constitution Chapter 2.

Interim Constitution Section 62 and 74.

7 For a discussion as to why South Africa chose a two-phase process instead of proceeding directly to a new Final Constitution, see, for instance, Dion Basson, South Africa's Interim Constitution, revised version 1995, Juta \& Co., Cape Town, p. 100 to 102; or Heinz Klug in: Constitutional Law of South Africa, 2nd revision 1998, Juta \& Co., Cape Town (hereinafter "COLSA"), p. 2-11 to $2-15$.

8 The Afrikaners, however, refer to them as the "Vryheidsoorlogen" (Wars of Freedom). For a very comprehensive account notably of the second war see Thomas Pakenham, The Boer War, Abacus ed. 1993.

9 Author's emphasis.

10

Thomas Pakenham, op.cit., p. 564. 
To say that there was no multiracial franchise is a truth requiring one important modification. In the Cape Colony there was a tradition of a no-colour-bar, and Black and Coloured ${ }^{11}$ Africans enjoyed the right to vote. They had to fulfil certain economic conditions, so, in practise, only the elite of the Blacks and Coloureds had the right to vote for the Cape parliament.

Article 8 provided that the Cape's multiracial franchise was not extended to apply in the defeated Transvaal and Orange Free State Republics. In order to further the reconciliation and integration of the two British colonies, the Cape and Natal, with the former republics, these areas were pushed towards a union. ${ }^{12}$

In the course of the negotiations on the constitution of such a union, a compromise was reached whereby the Cape's multiracial franchise would not be extended to the former republics and whereby Blacks and Coloureds at the Cape would retain the right to vote in accordance with the existing franchise regulations. Further, it was agreed that the existing voting rights of Blacks and Coloureds at the Cape, together with the equal status of the Dutch and English languages, should be protected by a so-called entrenched clause.

The entrenched clause laid down that changes involving a reduction of existing voting rights of Blacks and Coloureds would need to be passed by a two-third majority of both houses sitting together. ${ }^{13}$ The implication of this was that the entrenched sections in the Constitution could not be repealed by a normal act of Parliament. Any other sections of the Constitution could be changed by an act of Parliament passed by a simple majority as it normally can according to English law.

The English legal tradition that constitutional provisions can be changed by an act of Parliament passed by a simple majority differs fundamentally from most other countries where the constitution can only be changed in accordance with rules making it more complicated to carry out such a change. This is important to note because as we shall see below, it sets the background for the introduction of the supremacy of the constitution and the special rules for amending the Interim Constitution.

One cannot define a Coloured person with certainty. Normally, the expression refers to a person of mixed European, Asian or Black African descent.

Henning Viljoen / Dion Basson, South African Constitutional Law, Cape Town 1988, p. 37. Hereinafter referred to as Viljoen et al.

13

J.D. Omer-Cooper, History of Southern Africa, London 1989, p. 156. 


\section{Developments under the 1909-Constitution}

When the proposal for a constitution negotiated in South Africa came before the British parliament for adoption, once more the issue of the limited multiracial franchise was raised. However, once more the above-mentioned Article 8 was cited to explain why Britain could do nothing to stop the colour-bar in the new Union constitution. ${ }^{14}$

Upon its coming into force in 1910, section 35 of the South Africa Act of 1909 preserved the franchise for Blacks and Coloureds in the Cape. ${ }^{15}$

With the prevailing racial intolerance in South Africa, it is hardly surprising that the subsequent white governments sought to remove the limited multiracial franchise under the South Africa Act of 1909. This removal sets the stage for the discussion that follows below.

In 1926 the South African government sought to remove the franchise for the Blacks in the Cape. It was not until 1936, however, that the necessary majority in parliament could be secured for adoption of the Native Representation $\mathrm{Act}^{16}$ whereby the Blacks' right to vote was repealed. During this period the proportional importance of the black electorate in the Cape had been further diminished by granting the vote to all white women, and by the removal of all economic qualifications for white men. In place of the franchise, the Blacks were entitled to vote for three white members in parliament and two in the Cape Provincial

Pakenham, op.cit., p. 577. See also Omer-Cooper, op.cit., p. 157.

Section 35 stated:"(1) Parliament may by law prescribe the qualifications which shall be necessary to entitle persons to vote at the election of members of the House of Assembly, but no such law shall disqualify any person in the province of the Cape of Good Hope who, under the laws existing in the Colony of the Cape of Good Hope at the establishment of the Union, is or may become capable of being registered as a voter from being so registered in the province of the Cape of Good Hope by reason of his race or colour only, unless the Bill be passed by both Houses of Parliament sitting together, and at the third reading be agreed to by not less than two-thirds of the total number of members of both Houses. A Bill so passed at such joint sitting shall be taken to have been duly passed by both Houses of Parliament.

(2) No person who at the passing of any such law is registered as a voter in any province shall be removed from the register by reason only of any disqualification based on race or colour."

Viljoen et al., op.cit., p. 308 and 321, however, states that in terms of the South Africa Act 1909, Blacks and Coloureds were eligible for the Natal and the Cape Provincial Councils, but not for parliament.

It should be noted, however, that already in 1913, the South African parliament passed the Natives Land Act. This would have removed the multiracial franchise, had it not been for a judicial decision that made the act inoperative in the Cape Province. The reason for this was that the prohibition on Blacks purchasing land outside the reserves designated for them (the future Homelands), would have prevented them from satisfying the property qualification for the franchise, which was protected in the constitution, see Leonard Thompson, A History of South Africa, Massachusetts 1990, p. 163. 
Council. Black Africans in the country at large were to have the right to vote for four white senators. A Natives' Representative Council was set up, but it was a purely advisory body with no constitutional powers. ${ }^{17}$

In the thirties South Africa also gained its independence from Britain. The 1926 Imperial Conference in London declared the principles of full autonomy and equality with Britain for the dominions. And so following the 1930 Imperial Conference the British parliament passed the Statute of Westminster which repealed the Colonial Laws Validity Act regarding the dominions. Under the Colonial Laws Validity Act, South Africa could pass laws like an independent state, but was still subject to certain limitations. The British parliament could still pass laws and make them applicable to the dominions. Furthermore, Britain could invalidate an act of the South African parliament within a year with retrospective effect. ${ }^{18}$

Following the repeal of the Blacks' right to vote, the next step in dismantling the limited multiracial franchise in the South Africa Act of 1909 was to remove the Coloureds' right to vote. This was begun in 1948, but did not actually take place until 1956.

In 1948, the hitherto ruling party, the United Party, lost to the National Party in the general elections; a change of government which was to have serious repercussions for the Blacks and the Coloureds. The National Party was a much more Afrikaner dominated party, more right-wing and considerably less pro-British. ${ }^{19}$

One implication of the English electorate system is that the winner takes all. ${ }^{20}$ This combined with a certain over-representation of rural areas in parliament where most Afrikaners lived, meant that the joint forces of their votes gave the National Party a comfortable majority in parliament. It was still short of the necessary two-thirds majority to change the

Omer-Cooper, op.cit., p. 174, and Brian Lapping, Apartheid A History, Paladin Books 1987, Great Britain, p. 94. 1909 , section 65 .

19

It merits an article of its own to analyze all the factors responsible for this radical change. So for our immediate purposes, it is only noted that many Afrikaners had been unhappy about South Africa's alliance with Britain during the Second World War, instead of a position of neutrality, and the fact that the average Afrikaner was much poorer than the average English-speaking South African. In fact, in 1946 the average Afrikaner's income was only 47 percent of that of an English-speaking, see Thompson, op.cit., p. 188.

South Africa now has proportional representation, see Final Constitution Section 46 (1) which provides that the electoral system is prescribed by national legislation, is based on a common voters' roll, provides for a minimum voting age of 18 years and results, in general, in proportional representation. 
entrenched clauses on its own, but it had the political power to systematically initiate the grand scheme of separate development - better known as Apartheid.

In short, Apartheid was based on four ideas. First, the population of South Africa comprised four so-called racial groups - White, Coloured, Indian, and Black African - each with its own inherent culture. Second, Whites, as "the civilized race", were entitled to have absolute control over the state. Third, white interests should prevail over Black interests; the state was not obliged to provide equal facilities for the subordinate races. Fourth, the white racial group formed a single nation, while Blacks belonged to several (eventually ten) distinct nations or potential nations (the subsequent Homelands). ${ }^{21}$ This philosophy was the obvious reason for equality before the law not being introduced until in the Interim Constitution.

The change of government in 1948 also led to a change of policy towards Coloureds. So far they had been seen as an appendage of the white community and were ultimately to be absorbed by it. The National Party was, by contrast to the United Party, determined to segregate Coloureds from Whites as strictly as Blacks had been segregated from Whites.

By 1950, the South African government was of the opinion that as the Statute of Westminster had made South Africa a completely sovereign state, its parliament was a completely sovereign body ${ }^{22}$ and therefore it did not have to abide by any English law.

This idea of not having to abide by any English law led the South African government to adopt the Separate Representation of Voters Act 46 of 1951 which repealed section 35 of the South Africa Act of 1909. So the act was passed by simple majority by both Houses sitting separately. A court decision, known as the Harris-case, ${ }^{23}$ subsequently ruled that this law was invalid because the South Africa Act of 1909 required such an act to be passed by a two-third majority of both Houses in a joint session.

The government's response to circumvent this decision was to adopt the High Court of Parliament Act, under which parliament itself was made a supreme appeal court with overriding powers to judge the validity of legislation. After its adoption, parliament met and revalidated the Separate Representation of Voters Act. Once more the government was taken to court, and the High Court of Parliament Act was invalidated by the Appeal Court on the ground that the High Court of Parliament was parliament under another name.

21

Thompson, op.cit., p. 190.

22 The English, and by derivation South African, constitutional principle of a sovereign parliament will be discussed more in detail below.

23

Harris v. Minister of the Interior 1952 (2) SA 428 (A). For a further discussion on the Harris-case, see Part 6 below. 
The government thereafter decided to follow the procedure laid down in the South Africa Act of 1909, and two attempts to obtain a two-third majority of both Houses failed narrowly, before the government came up with an idea that was to work, namely by having parliament adopt two fairly innocent looking acts. One of these two acts enlarged the Senate and modified the procedures for the election of Senators to ensure an increased nationalist majority as well as enlarging the number of government appointed appellate judges from five to eleven. The other of these two acts reinvalidated the 1951 Separate Representation of Voters Act and denied the courts the competence to inquire into its validity. This act was, thanks to the enlarged Senate, passed with a sufficient majority of both Houses sitting jointly. Upon appeal, the enlarged and now more government-friendly Appeal Court found the act valid and thereby finally repealed section 35 . Following this repeal, Coloureds were removed from the common roll at the Cape. They would then be registered on a separate roll and be allowed to elect four whites to represent them in the House of Assembly, one in the Senate, and two on the Cape Provincial Council. ${ }^{24}$

With this legal manoeuvre the Cape's multiracial franchise was finally destroyed in 1956.

\section{Developments under the 1961- and 1983-Constitution}

As the winds of decolonization began to sweep the African continent in the fifties, South Africa took a hard course against the wind. Soon South Africa's racial policies gained the attention of the International Community. Then and for the next three decades.

In 1961, South Africa had its second constitution, Act 32 of 1961, as the result of a referendum whereby the white electorate decided to turn South Africa into a republic which would detach South Africa from the last formal links with Britain. Furthermore, because of stiff opposition amongst the member states of the British Commonwealth, South Africa withdrew from the association. ${ }^{25}$ Apart from a change of denomination of the head of state, no important changes took place on the constitutional level ${ }^{26}$ following the adoption of the 1961 Constitution.

In the sixties and seventies, Apartheid was at its highest point of oppression. During these two decades the International Community's growing awareness of the plight of non-white South Africans mirrored the internal opposition to Apartheid.

The parliamentary seats of white representatives of both Black and Coloured voters were to be abandoned fifteen years later, see Thompson, op.cit., p. 187.

25

Thompson, op.cit., p. 188.

26

Viljoen et al., op.cit., p. 41. 
Eventually, South Africa's government had go give in to the pressures on the national and international level and undertake some reform. After a referendum, it was decided to give South Africa a more equitable and broader political platform, racially speaking, which led to the adoption of the Republic of South Africa Constitution Act 110 of 1983. Under section 52 of the 1983 Constitution, "every white person, Coloured person and Indian" had the right to vote subject to certain legal conditions. ${ }^{27}$

The 1983 Constitution did not appease the situation in South Africa, and the Coloured and Indian population groups only gave the reform a very limited support because, after all, the 1983 Constitution was little more than window-dressing since the Whites still held the reins of power. The obvious and major short coming of this constitution was that about 75 percent of the population, including the homelands, had no say in the governing of South Africa $^{28}$.

For our immediate purposes, it is not necessary to give a detailed description of the decade between the 1983 Constitution and the 1993 Interim Constitution, other that to recall that the last years' of Apartheid led to enormous human sacrifices due to politically motivated violence. The unrest in South Africa grew so alarming, in fact, that a general state of emergency was declared from 1986 to 1989. Furthermore, between 1983 and 1993 South Africa's economy suffered greatly under the economic sanctions which had finally been imposed on South Africa by the Commonwealth Countries, the United States of America, and the European Community.

The pressures on the government for change never ceased, even if the government did try to abandon various pieces of legislation which were not strictly necessary in order to keep the Whites in power. Finally, in 1989 there was a change of political leadership in the National party which had been in office since 1948. The change of political leadership soon paved

27 The new parliament looked something of a Belgian compromise, consisting of three chambers: a white House of Assembly, a Coloured House of Representation, and an Indian House of Delegates. However, the number of votes were so divided between the Houses that the whites had a comfortable majority in a joint session. A multiracial cabinet drawn from the three houses was responsible for so-called general affairs, such as taxation, foreign affairs, defense, state security, law and order, commerce and industry. Uniracial ministers councils were responsible for so-called own affairs, comprising fields such as education, health, and local government. The State president, who had more powers now than under the previous two constitutions, appointed the members of the cabinet and the ministers councils. Furthermore, the president could dissolve parliament at any time and decide what was to be considered general affairs and own affairs and was lastly responsible for the control and administration of black affairs, see Thompson, op.cit., p. 225 and the 1983 Constitution, Sections 14 and 16.

Thompson, op.cit., p. 225. 
the road towards negotiations on a new constitution introducing a multiracial democracy and the subsequent adoption of the Interim Constitution. ${ }^{29}$

The Interim Constitution did, as mentioned above, further seek to have future effects for the Final Constitution. The Interim Constitution contained a Schedule 4 on Constitutional Principles which, under Section 73, the Constitutional Assembly (the National Assembly and the Senate sitting jointly) was legally obliged to follow during the negotiations on the Final Constitution. One of these principles is that everyone shall enjoy all universally accepted fundamental rights, freedoms and civil liberties, which shall be provided for and protected by entrenched and justiciable provisions in the Constitution, which shall be drafted after having given due consideration to, inter alia, the fundamental rights contained in Chapter 3 of this Constitution. ${ }^{30}$

To safeguard this constitutional principle even further, Section 74 (1) in the Interim Constitution provided that the Constitutional Principles could neither be amended nor repealed. This meant that there was no way that the Constitutional Assembly could have decided to omit the universal right to vote in the Final Constitution, and this was the means by which the authors of the Interim Constitution sought to give future protection to the right to vote.

On 8th May 1996 the Constitutional Assembly adopted the Final Constitution. Under the Interim Constitution, the Constitutional Court had to certify that the Final Constitution complied with the Constitutional Principles. On 6th September 1996, the Constitutional Court declared that the Final Constitution did not comply with the Constitutional Principles, among others, on the grounds that the Final Constitution did not give enough competence to the local governments. In terms of the Interim Constitution, the relevant parts of the Final Constitution had to be drawn up once more. This eventually happened, and the Constitutional Court gave its permission to President Mandela to sign the Final Constitution in Sharpeville on 10 December 1996. The Final Constitution came into force on 4 February $1997 .^{31}$

Several books deal with these negotiations and the last years of Apartheid; the best know probably being president Nelson Mandela's own "Long Walk To Freedom".

30 Author's emphasis.

31 The Interim Constitution was likewise repealed. Court Cases pending at the moment of the entry into force of the Final Constitution will still be heard according to the Interim Constitution. 


\section{The 1993 Interim Constitution}

\section{a) Franchise}

Finally and for the first time in South African history, the Interim Constitution of 1993 introduced a universal right to vote. Section 6 reads:

"6. Every person who is -

(a) (i) a South African citizen; or

(ii) not such a citizen but who in terms of an Act of Parliament has been accorded the right to exercise the franchise;

(b) of or over the age of 18 years; and

(c) not subject to any disqualifications as may be prescribed by law, shall be entitled to vote in elections of the National Assembly, a provincial legislature or a local government and in referenda or plebiscites contemplated in this Constitution, in accordance with and subject to the laws regulating such elections, referenda and plebiscites."

The nature of the contents of section 6 was such that this section could be in any constitution of any of the countries which are normally considered to be democratic states. To subject the right to vote to conditions such as having to be a South African citizen or a naturalized person, to be of or over 18 years, and not to be subject to any disqualifications as may be prescribed by law, are conditions which do not negate a universal right to vote and are justifiable in a normal democratic society. ${ }^{32}$

\section{b) Supremacy of the constitution}

In the introduction to this article it was suggested that a description of the franchise in a historical context would provide examples to illustrate the background for several of the innovations in the Interim Constitution. In the following we shall have a closer look at the section of the Interim Constitution whereby the principle of the Supremacy of the Constitution was introduced. Section 4 reads:

"(1) This Constitution shall be the supreme law of the Republic and any law or act inconsistent with its provisions shall, unless otherwise provided expressly or by necessary implication in this Constitution, be of no force and effect to the extent of the inconsistency.

32

Dion Basson, South Africa's Interim Constitution, revised version 1995, Juta \& Co. Ltd., Cape, p. 12. 
(2) This Constitution shall bind all legislative, executive and judicial organs of state at all levels of government."

To someone with a Continental European legal background, it is almost self-evident that there is a hierarchy of laws and that no other law, not even an act of parliament, ranks higher than the constitution. This principle, however, was an innovation in South Africa. Section 4 was one of the most important sections in the entire Interim Constitution.

The former South African constitutions derived from the British constitutional system in which the principle of a sovereign parliament applies, i.e. that parliament is the supreme legislative authority. ${ }^{33}$ In South Africa traditionally the principle of a sovereign parliament is discussed in relation to the courts' testing rights of acts of parliament. In the British system the courts are subordinate to the parliament and can therefore not test the validity of an act of parliament.

In relation to the issue of franchise, the question of testing rights proved to be a question as to how the entrenched clause on the limited multiracial franchise was working under the South Africa Act of 1909.

As we have already seen, by 1950 , the South African government was of the opinion that it did not have to respect the "entrenched" section 35 in the South Africa Act of 1909, because Parliament was a completely sovereign body. The fact that the court in the abovementioned Harris-case did declare the Separate Representation of Voters Act 46 of 1951 invalid, was considered to be a watershed decision as regards the courts' testing rights, since so far the courts had been considered not to have any testing rights, not even procedural ones. However, the Harris-case was the first of several cases to establish that the courts had a procedural testing right. ${ }^{34}$ A procedural testing right means that the courts can check if the Parliament has adopted an act of Parliament in accordance with the formal rules laid down for adoption of such an act.

Under the subsequent 1961 Constitution, the courts' testing rights remained procedural. The 1961 Constitution even had a clause ${ }^{35}$ laying down that, except for the competence to pronounce judgement on the question whether the special, prescribed procedures of the entrenched provisions had been observed, no court of law was competent to settle the matter of validity of a parliamentary act. This section was understood so that the courts 
could pass no judgement on the content of an act of parliament, but could do so on the question whether a specific instrument was, in fact, an act of parliament. ${ }^{36}$

Under the 1983 Constitution, the Supreme Court of South Africa was "competent to inquire into and pronounce upon the question as to whether the provisions of this Act [i.e. the 1983 Constitution itself] were complied with in connection with any law ...". The rule regarding acts of parliament other than the 1983 Constitution itself did, however, remain that "no court shall be competent to inquire into or pronounce upon the validity of an Act of Parliament". 37

Under a constitutional system where parliament was sovereign, parliament became, as South Africa's history shows with clarity, a very dangerous institution in the hands of a majority government, and there was little the courts could do to declare legislation invalid, without regard to actual or implied content. ${ }^{38}$ Under Section 4 of the Interim Constitution the courts' testing rights were extended beyond purely procedural ones.

\section{c) Protection of the right to vote}

In the introduction it was mentioned that, under the Interim Constitution, the rule no longer applied that the provisions in the constitution could be changed by an act of parliament passed by a simple majority. In the Interim Constitution all clauses were so to speak "entrenched clauses". If we now look at the rules on changing the provisions of the Interim Constitution, it will serve as an illustration of how the authors of the Interim Constitution have sought to prevent it from being unjustly changed.

The general rule as regards bills amending the Interim Constitution in Section 62 (1) required such bills to be adopted at a joint sitting of the National Assembly and the Senate by a majority of at least two-thirds of the total number of members of both Houses. This did not mean that section 6 on the universal right to vote could be amended under this general rule, because the Interim Constitution contained special rules regarding the franchise in Chapter 3. Section 21 (2) therein stated that the right to vote was included amongst the fundamental rights. ${ }^{39}$ The inclusion of the right to vote among the fundamental rights had

36

37

38

In the light of the then prevailing racial intolerance, one can speculate, however, if not the courts would have resisted the circumvention of the South Africa Act 1909 with more zest if the issue had been to abandon the English language as an official language.

39 Section 21 (2) read: "Every citizen shall have the right to vote, to do so in secret and to stand for election to public office." Further, although it may seem a little unnecessary in the light of section 
the important legal consequence that the right to vote was subject to the special rules in Section 33 on limitation of fundamental rights. In keeping with the principle that no fundamental right is absolute, Section 33 provided a method or mechanism for the courts to implement if called upon to decide the question of when a limitation on a fundamental right will be legitimate and valid. ${ }^{40}$ The relevant part of section 33 (1) reads:

"(1) The rights entrenched in this Chapter may be limited by law of general application, provided that such limitation -

(a) shall be permissable only to the extend that it is -

(i) reasonable; and

(ii) justifiable in an open and democratic society based on freedom and equality; and

(b) shall not negate the essential content of the right in question, and provided further that any limitation to -

a right entrenched in section ... $21, \ldots$

$\cdots$

shall, in addition to being reasonable as required in paragraph (a)(i), also be necessary." 41

This section's conditions for limiting a fundamental right made it not only very hard to justify a limitation of the right to vote, it even implied that the South African Constitutional Court and Supreme Court ${ }^{42}$ would have to inquire into the validity of an act on the basis of the content of an act limiting the right to vote; in other words, as regards alleged violations of the fundamental rights the former procedural testing rights of the courts were replaced by a right which amounts to a complete testing right. ${ }^{43}$

It seems to follow from the wording of Section 33 that the Constitutional Court is to use a test implying shifting levels of scrutiny where some rights can be limited if the limitation is

4, section 7 provided that the Interim Constitution's chapter 3 on fundamental rights shall bind all

40

41

42

43

Furthermore, it should be noted that the individual citizen's possibility to challenge the validity of an act, which is possibly inf ringing a fundamental right, has been enhanced considerably. By introducing the general principle that any person acting in the public interest shall be entitled to apply to a competent court of law for appropriate relief, see Interim Constitution Section 7(4)(a) and(b). 
"reasonable" and other only if the limitation is "reasonable" and "necessary". ${ }^{44}$ It is, however, not possible to say how the Constitutional Court applies this mechanism because it has been extremely reluctant to develop clearly distinct tests for those rights and freedoms which receive reasonable and necessary protection under the limitations clause and those which simply receive reasonable protection. ${ }^{45}$ Indeed, the President of the Constitutional Court even said in S. v. Makwayane that "different rights have different implications for ... an open and democratic society based upon freedom and equality" and that "means that there is no absolute standard which can be laid down for determining reasonableness and necessity".

\section{The $\mathbf{1 9 9 6}$ Final Constitution}

\section{a) Continuity}

As regards the right to vote and the principle of the supremacy of the constitution, the Final Constitution carries these principles from the Interim Constitution into the future. The principle of the supremacy of the constitution is included among the founding provisions in chapter one of the Final Constitution, ${ }^{46}$ and the right to vote is included both among these founding provisions and in the Bill of Rights in chapter two. ${ }^{47}$

44 The leading cases regarding the use of section 33 seem to be: S v. Makawanyane 1995(3) SA 391(CC), 1995 (2) SACR 1 (CC), 1995 (6) BCLR 665 (CC); Ferreira v. Levin 1996 (1) SA 984(CC), 1996 (1) BCLR 1 (CC); Coetzee v. Government of RSA 1995(4) SA 631 (CC), 1995 (10) BCLR 1382(CC).

45 See Stuart Woolman, in: COLSA, p. 12-13.

46 In the Final Constitution section 1 (c) and section 2 respectively read:

"1. The Republic of South Africa is one sovereign democratic state founded on the following values:

(c) Supremacy of the constitution and the rule of law."

"2. This Constitution is the supreme law of the Republic; law or conduct inconsistent with it is 47 invalid, and the duties imposed by it must be performed."

In the Final Constitution: Section 1 (d) reads:

"The Republic of South Africa is one sovereign democratic state founded on the following values:

(d) Universal adult suffrage, a national common voters roll, regular elections, and a multi-party system of democratic government, to ensure accountability, responsiveness and openness."

Section 19 (3)(a) reads:

"Every citizen has the right -

(a) to vote in elections for any legislative body established in terms of the Constitution, and to do so in secret; and". 


\section{b) Protection of the right to vote in the Final Constitution}

On the constitutional level the right to vote is enshrined in section 1(d) and 19(3)in the Final Constitution. When it comes to amending the Constitution it should be noted that Section 1 in terms of Section 74 requires a higher majority of the National Assembly to amend Section 1 than Section 19, and to the extent that the two provisions correspond, the higher degree of entrenchment also applies to Section $19 .{ }^{48}$ As regards the limitation clause it is of interest that the new limitation clause in Section $36^{49}$ is not identical to its predecessor in the Interim Constitution, in that it seems to apply a general approach, taking all relevant factors into account, without different levels scrutiny. The case law relating to section 33 of the Interim Constitution will therefore be of limited importance. It is, however, still too early days to say how the Constitutional Court will apply this general approach.

\section{c) Protection of the right to vote on statute level}

On the statute level, the Electoral Act 78 of 1998 is of more direct importance to the individual citizen. ${ }^{50}$ The Electoral Act not only stipulates that the voter needs to be a South African citizen of 18 years of age and that his or her name must appear on the voters' roll, the Electoral Act further provides a more tangible protection of the right to vote in that it is made an of fense for a person to compel or unlawfully persuade another person to vote in a

48

49 In the Final Constitution Section 36 reads:

"(1) The rights in the Bill of Rights may be limited only in terms of law of general application to the extent that the limitation is reasonable and justifiable in an open and democratic society based on human dignity, equality and freedom, taking into account all relevant factors including-

(a) the nature of the right;

(b) the importance of the purpose of the limitation;

(c) the nature and extent of the limitation;

(d) the relation between the limitation and its purpose; and

(e) less restrictive means to achieve the purpose.

(2) Except as provided in subsection (1) or in any other provision of the Constitution, no law may limit any right entrenched in the Bill of Rights."

50

51

This act came into force on 16 October 1998 and replaced the Electoral Act 202 of 1993 which was in force during the 1994-elections.

Section 1. Under Section 13, a complaint over a refusal by a chief electorate of ficer to register a person on the voters' roll can be appealed to the Electoral Commission whose decision cannot be appealed, unless the decision of the Commission relates to the interpretation of any law or any matter for which an appeal is provided by law, in which case it is heard by the Electoral Court which has status of Supreme Court, see Section 20(2)(a) of Electoral Commission Act 51 of 1996. A supreme court is the highest court of appeal except in constitutional matters, see Final Constitution Section 169. 
particular way. ${ }^{52}$ The secrecy of the vote is also secured and a contravention thereof is sanctioned as an of fence. ${ }^{53}$ In the light of the limitation clause mentioned above, it may be of more interest to note that the Electoral Act defines what classes of citizens are excluded from the right to vote. A person who has been declared by the High Court to be of unsound mind or mentally disordered or who is detained under the Mental Health Act 18 of 1973 is not entitled to vote. ${ }^{54}$ Unlike under the former Electoral Act, now all prisoners can vote. ${ }^{55}$

\section{Conclusion}

In this article we have not sought to prove some legal thesis, but to enhance a non-South African person's understanding of the legal and historical framework of some of the fundamental constitutional changes that have been taking place in South Africa. The authors of the Interim Constitution produced a very modern and, for South Africa at that time, revolutionary constitution which has served as the foundation of her Final Constitution. The restraint and pragmatism shown by the parties is, in the light of the immense human sacrifices in the past, noteworthy, indeed. South Africa's Final Constitution sets up a modern system which seeks very extensively to respect human rights and minority rights. Thus, for example, the combination of a national government and local governments mirrors the intention to keep the Republic a united territory which allows for regional differences. Or as the first country ever to include non-discrimination on sexual orientation in its Bill of Rights. The Final Constitution provides the democratic foundation that South Africa needs if she is to continue to prosper not only for the benefit of her own population, but also for that of her neighbours within Southern Africa.

The Final Constitution, and even more so the Interim Constitution, may serve as an example of how a nation tried to overcome its violent and troublesome history in order to

Sections 87(1)(a) \& 89(1). Under Section 98(b), a contravention of Section 89(1)(a) can be sanctioned by a fine or imprisonment for a period not exceeding five years.

Section 90(1). Under Section 98(a) a contravention can be sanctioned by a fine or imprisonment for a period not exceeding 10 years.

54

Section 8 (2)(c) \& (d).

Section 16 (d) of the former Electoral Act excluded prisoners convicted for murder, robbery with aggravating circumstances, and rape, and attempts to commit those offenses from voting. This issue caused much controversy in South Africa before the 1994-elections, and the former Electoral Act was amended shortly before the elections in order to allow more prisoners to vote. Before this amendment South African law excluded a vast number of prisoners convicted for very various (some rather petit) kinds of offenses from voting, see, for instance, Johan de Wall, in: COLSA, p. 23-15, notably footnote 3. Further note that in Masuku and Mbonani $v$ The State President and others (1994(4)SA 374 (T)), two prisoners, convicted for murder, contended that Section 16 of the former Electoral Act was inconsistent with the Interim Constitution's political rights and right to equality. Unfortunately, this case could not be heard on formal grounds. 
heal the divisions of the past and establish a society based on democratic values, social justice and fundamental rights, and as such they may hold lessons for other emerging democracies.

Nkosi Sikelel'i Afrika!

\section{Appendix \\ Chronological Summary of Important Events}

1899: The Transvaal Republic and The Orange Free State Republic declare war on the British. The beginning of the Second Boer War.

1902: The Second Boer War ends with the conclusion of a peace treaty.

1909: The British Parliament adopts the first constitution of The Union of South Africa.

1926: The South African government's first attempt to remove the franchise for the Black Africans in the Cape.

1930: South Africa gains its independence from Britain as a result of the Statute of Westminster.

1936: The franchise for the Black Africans in the Cape is removed.

1948: The so far ruling party, The United Party, looses to The National Party in the general elections.

1951: The South African's government's first attempt to remove the franchise for the Coloureds in the Cape by passing of the Separate Representation of Voters Act.

1952: The Separate Representation of Voters Act is declared invalid by a court (The Harris case).

1956: The South African government is successful in removing the Coloureds' franchise after having packed the Senate and the Supreme Court.

1961: South Africa becomes a republic as a result of its second constitution.

1983: South Africa has its third constitution granting the right to vote to Whites, Indians, and Coloureds.

1989: Change of political leadership in the National Party.

1993: Adoption of The Interim Constitution.

1996: Adoption of The Final Constitution.

1997: The Final Constitution enters into force.

1999: First General Elections under the Final Constitution. 
legal foundation at all. The uti possidetis merely answers the question of the boundaries between new states which have effectively reached independence. To do that neither requires the existence of a right of peoples to external self-determination, nor does it contradict such a right. Quite on the contrary: Since any "people" (may it be ethnically, religiously etc. defined) striving for independent statehood as the result of the right to external self-determination needs a defined territory, the uti possidetis plays an important (though indirect) role in defining the "people" by giving it a territorial basis: inside the administrative boundary lines. At least as far as the "peoples" on the territory of former Yugoslavia and the former USSR (as well as earlier on during decolonization in Africa and Asia) are concerned, such a territorial definition is crucial due to an eminent lack of other substantial unifying factors.

\section{The Right to vote in South Africa - A Hundred Years of Experience}

\section{By Klavs Skovsholm}

June 1999 is witness to the first elections under the Final Constitution of South Africa and the resignation of President Nelson Mandela. This is a historic step and the culmination of a long and difficult process. The article focuses on the right to vote in South Africa under her five constitutions respectively of 1909, 1961, 1983, 1993 (Interim) and 1996 (Final). Special emphasis is placed on the 1909, the Interim and Final Constitutions.

The historical approach puts two new constitutional principles in South Africa into perspective: namely the universal right to vote and the supremacy of the Constitution. The universal right to vote was an impossibility until 1993 because of the Apartheid ideology. The supremacy of the Constitution was non-existent because of the British legal tradition of a sovereign Parliament. Further, history shows with clarity how dangerous the principle of a sovereign Parliament can be under unfortunate conditions.

The article further looks at related issues such as the chapter on fundamental rights, the testing rights of the courts and the rules regarding constitutional amendments in the Interim and the Final Constitutions. Also, it considers at the protection of the right to vote on a constitutional level as well as on a statute level.

In its conclusion, it is argued that the Interim and the Final Constitutions may hold lessons for other emerging democracies. 